\title{
Association between nonalcoholic fatty liver disease and extrahepatic cancers: a systematic review and meta-analysis
}

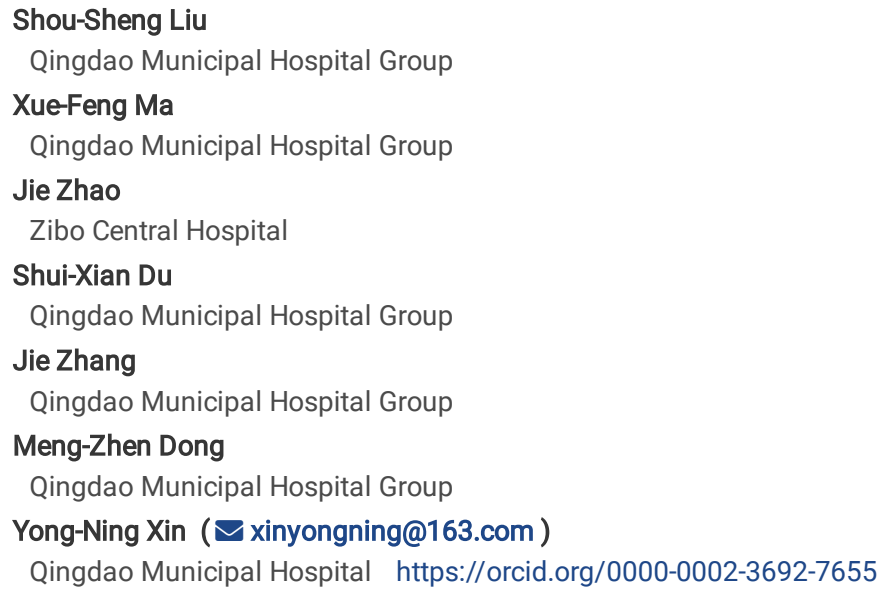

Version of Record: A version of this preprint was published at Lipids in Health and Disease on May 31st, 2020. See the published version at https://doi.org/10.1186/s12944-020-01288-6. 


\section{Abstract}

Background: NAFLD is tightly associated with various diseases such as diabetes, cardiovascular disease, kidney disease, and cancer. Previous studies had investigated the association between NAFLD and various extrahepatic cancers, but the available data to date is not conclusive. The aim of this study was to investigate the association between NAFLD and various extrahepatic cancers comprehensively.

Methods: Searches were conducted of various electronic databases (PubMed, EMBASE, Medline, and the Cochrane Library) to identify observational studies published between 1996 and January 2020 which investigated the association between NAFLD and extrahepatic cancers. The pooled OR/HR/IRR of the association between NAFLD and various extrahepatic cancers were analyzed.

Results: A total of 26 studies were included to investigate the association between NAFLD and various extrahepatic cancers. As the results shown, the pooled OR values of the risk of colorectal cancer and adenomas in patients with NAFLD were 1.72 (95\%Cl: 1.40-2.11) and 1.38 (95\%Cl: 1.22-1.56), respectively. The pooled OR values of the risk of intrahepatic cholangiocarcinoma and extrahepatic cholangiocarcinoma in patients with NAFLD were 2.40 (95\%Cl: $1.75-3.31)$ and 2.24 (95\% Cl: 1.58-3.17), respectively. The pooled OR value of the risk of breast cancer in patients with NAFLD was 1.68 (95\%Cl: 1.44-1.97). In addition, NAFLD was also tightly associatied with the risk of gastric cancer, pancreatic cancer, prostate cancer, and esophagus cancer.

Conclusions: NAFLD could significantly increase the development risk of colorectal adenomas and cancer, intrahepatic and extrahepatic cholangiocarcinoma, breast cancer, gastric cancer, pancreatic cancer, prostate cancer, and esophagus cancer.

\section{Introduction}

Nonalcoholic fatty liver disease (NAFLD) has become one of the most prevalent chronic liver diseases globally. Currently, it has an estimated overall prevalence of $25.2 \%$ worldwide, and $29.62 \%$ in Asia [1-4]. The disease spectrum of NAFLD ranges from nonalcoholic fatty liver to nonalcoholic steatohepatitis (NASH), fibrosis, cirrhosis, and eventually to the hepatocellular carcinoma [5]. Considering the key physical functions of the liver, NAFLD is a complex multifactorial disease which involves sedentariness, obesity, poor dietary habit, sarcopenia, insulin resistance, genetic susceptibility, intestinal flora and other factors [6-9]. In addition, NAFLD has been found to be closely related to many diseases such as diabetes, cardiovascular disease, and kidney disease. Thus, NAFLD is a multisystem disease with extrahepatic complications [10-16].

Accumulated evidences have shown that cardiovascular disease is the leading cause of death in patients with NAFLD, and malignancies at both gastrointestinal (liver, colon, esophagus, stomach, and pancreas) and extra-intestinal site (kidney in men, and breast in women) were also significant contributors to the mainly death of patients with NAFLD $[17,18]$. Wongiarupong et al. conducted a meta-analysis to investigate the association of NAFLD with the risk of cholangiocarcinoma [19]. In the study, they found that NAFLD potentially contributes to the risk of developing cholangiocarcinoma [19]. Lee et al. also recently reported an association between NAFLD and esophageal, stomach, or colorectal cancers in Korea [20]. Mortality rates in NAFLD patients with any of these three types of cancer were markedly increased, suggesting a significant association between NAFLD and the risks of esophageal, stomach, or colorectal cancers [20].

Recently, Lots of attentions have been paid to the association between NAFLD and extrahepatic cancers. For example, Allem et al. have investigated the effect of NAFLD on the occurrence rate of extrahepatic cancers in a US population [21]. NAFLD was found to be associated with a $90 \%$ higher risk of cancer, which included uterine, stomach, pancreas, and colon cancers [21]. Due to differences in risk factors associated with various types of cancers in several countries, there is no consensus about the linkage between NAFLD and extrahepatic cancers.

The aim of this study was to identify the association between NAFLD and extrahepatic cancers comprehensively, and update the previous results of the overall association between NAFLD and extrahepatic cancers.

\section{Methods}

\section{Search Strategy}

The multiple systematic reviews and meta-analysis of the available studies relying on the Preferred Reporting Items for Systematic Reviews and MetaAnalyses (PRISMA) statement for the conduct of meta-analysis of observational studies were performed [22]. The following cancers were included in this study: 1) Colon neoplasm; 2) Cholangiocarcinoma; 3) Breast cancer; 4) Gastric cancer; 5) Pancreatic cancers; 6) Prostate cancer; 7) Esophageal cancer. Separate meta-analyses were performed for colon neoplasms, cholangiocarcinoma, and breast cancer. Relevant studies were identified by searching PUBMED, EMBASE, MEDLINE, and the Cochrane Systematic Review Database for studies published between 1996 and January 2020 . The following search terms were used: Colon neoplasm, colon cancer, colorectal cancer, gastric neoplasm, stomach neoplasm, stomach cancers, gastric cancer, pancreatic neoplasm, pancreatic cancers, PDAC, PaC, esophageal neoplasm, esophageal cancer, breast carcinoma, breast cancer, breast neoplasm, breast tumor, breast malignant neoplasm, prostate neoplasms, prostate cancer. Only the observational studies (i.e., case-control studies and cohort studies) and written in English language were considered eligible for inclusion in this meta-analysis. Studies were excluded if they were only published as abstracts.

\section{Inclusion and Exclusion Criteria}

The initially retrieved publications were reviewed by two investigators (Shou-Sheng Liu and Xue-Feng Ma) independently. Discrepancies were resolved by discussion with all investigators. Studies were included if they meet the criteria as follows: 1) studies explored the correlation between NAFLD and related cancers; 2) NAFLD or NASH was defined by either histopathological examination, imaging study or International Classification of Diseases, Ninth Revision (ICD-9) or ICD-10 codes, Hepatic steatosis index; 3) extrahepatic cancers were also defined by either histopathological examination, imaging study or ICD-9 or 
ICD-10 codes; 4) risk estimates (odds ratios [ORs], hazard ratios [HRs] or incidence rate ratios [IRRs]) with their corresponding 95\% confidence intervals (Cls) were reported or could be calculated from the data provided; 5) studies were published full-text report in English language. The following studies were excluded: abstracts, reviews, case reports, and letters. Studies that did not provide sufficient data to calculate the risk estimates were also excluded.

\section{Quality Assessment}

Quality of the included studies was assessed independently by two authors (Shousheng Liu and Xuefeng Ma) according to the Newcastle-Ottawa Scale (NOS) [23]. The NOS is comprised of three sections: selection (up to 4 points), comparability (up to 2 points), and outcome (up to 3 points). The maximum score is 9 points. Study quality was classified as poor (score, 0-3), fair (score, 4-6), or good (score, 7-9). Discrepancies were resolved by discussion with all investigators.

\section{Data Extraction}

The following information was extracted from each study: first author, publication year, country, number of subjects, diagnosis method of NAFLD, source of patients, dates of the study, study design, diagnosis method for each cancer, adjusted confounding factors, and study quality. The data were collected independently by two investigators (Shou-Sheng Liu and Xue-Feng Ma).

\section{Data Synthesis and Analyses}

Correlations between NAFLD and related cancers were calculated by OR with corresponding $95 \% \mathrm{Cl}$. In forest plots, OR > 1 represented a risk effect, while OR < 1 represented a protective effect. Because the overall risk of extrahepatic cancers is low, HRs and IRRs in the cohort studies were similar to the ORs in the casecontrol studies mathematically. Thus, a combination of case-control and cohort studies was appropriate. Statistical heterogeneity among the studies was assessed according to $\mathrm{Q}$ and $P^{2}$ statistics. For the Q statistic, heterogeneity was considered present when $P<0.1$ or $P>50 \%$. A fixed-effect model was used when literature heterogeneity did not exist; otherwise, a random-effect model was used. Publication bias was evaluated visually with funnel plots. Publication bias was considered significant when $P<0.05$ in Begg's test. Subgroup analyses were performed according to the design of the study. Pooled ORs were calculated by using STATA 13.0 software (Stata Corporation, College Station, TX, USA).

\section{Results}

\section{Literature search and study characteristics}

A total of 3221 published studies were identified as potentially relevant from the databases searched. After removing animal studies, reviews, and nontopic studies, 1311 studies were retrieved for evaluation. After case reports, comments, non-English written articles, duplicates, and irrelevant resources were further removed, 131 studies remained for detailed evaluation. After excluding the studies which did not provide information regarding proportions, and those which did not include full text, 26 studies were included for systematic review and meta-analysis [21, 24-48] (Figure 1). Among these selected studies, some included two or more types of the following cancers: gastrointestinal $(n=15)$, cholangiocarcinoma $(n=7)$, breast $(n=4)$, gastric $(n=3)$, pancreatic $(n=3)$, prostate $(n=$ $3)$, and esophageal $(n=2)$.

\section{Association between NAFLD and gastrointestinal cancer}

Fifteen of our selected studies evaluated relationships between NAFLD and risk of gastrointestinal cancers (e.g., colorectal cancer and colorectal adenoma) (Table 1). Among these studies, 7 were conducted in South Korea, 5 were conducted in China, 1 was conducted in Austria, 1 was conducted in Japan, and 1 was conducted in the USA. All of these studies were observational and included 6 cohort studies and 9 cross-sectional studies. According to NOS scores, 11 were high quality and 4 were fair quality (Table 2).

To investigate the association between NAFLD and the risk of colorectal cancer, pooled OR of colorectal cancer from ten studies was analyzed [21, 24-32]. A meta-analysis was conducted with the random-effect model $\left(P<0.01, P^{2}=83.5 \%\right)$. The results indicated that patients with NAFLD have a significant risk of developing colorectal cancer $(\mathrm{OR}=1.72,95 \% \mathrm{Cl}: 1.40-2.11)$ (Figure $2 \mathrm{~A})$. Publication bias was also tested by using Begg's test. The results suggested that an obvious publication bias exists among these studies $(P<0.01)$ (Figure $4 \mathrm{~A})$. Furthermore, the results of a subgroup analysis showed that the pooled OR of colorectal cancer in the cross-sectional studies $[25,26,28,30,31]$ was $1.93(95 \% \mathrm{Cl}: 1.48-2.53)$, and in the cohort studies [21, 24, 27, 29, 32] it was $1.52(95 \%$ Cl: 1.18-1.95) (Table 1, Figure 2A).

To investigate the association of NAFLD and the risk of colorectal adenoma, pooled OR of colorectal adenomas from nine studies was analyzed [27-30, 32-35, 46]. A meta-analysis was conducted with the random-effect effect model $(P=0.045, P=49.4 \%)$. The results indicated a significant developmental risk of colorectal adenoma in patients with NAFLD (OR $=1.38,95 \% \mathrm{Cl}$ : 1.22-1.56) (Figure 2B). When publication bias was tested, Begg's test indicated no obvious publication bias $(P=0.754)$ (Figure $4 \mathrm{~B})$. Furthermore, the results of subgroup analysis showed that the pooled OR of colorectal adenoma in the crosssectional studies [27, 29, 30, 33-35, 46] was 1.35 (95\% Cl: 1.17-1.55), and in the cohort studies [29, 33] it was 1.55 (95\% Cl: 1.18-2.03) (Table 1, Figure 2B). These results suggest that patients with NAFLD have a higher risk of developing colorectal cancer and colorectal adenoma than patients without NAFLD.

\section{Association between NAFLD and cholangiocarcinoma}

In this systematic review and meta-analysis, seven studies were included to evaluate relationships between NAFLD and the risk of cholangiocarcinomas [including intrahepatic and extrahepatic cholangiocarcinomas (ICC and ECC, respectively)] [37-43]. Three of these studies were conducted in the United States, 1 was conducted in Europe, 1 was conducted in China, 1 was conducted in Japan, and 1 was conducted in South Korea. All of these studies were cross- 
sectional studies. In addition, patients in four studies were from the community, while three studies were from hospital. According to NOS scores, 4 studies were high quality and 3 studies were fair quality (Table 3 ).

To investigate the association of NAFLD and the risk of ICC, pooled OR of ICC from seven studies was analyzed [37-43]. A meta-analysis was conducted with the random-effects model $\left(P=0.004, P^{2}=68.4 \%\right)$. The results showed a significant risk of developing ICC in patients with NAFLD (OR $=2.40,95 \%$ Cl: $1.75-$ 3.31) (Figure 3A). In addition, according to Begg's test, no obvious publication bias was observed among these studies $(P=0.501)$ (Table 1, Figure 4C). To investigate the association of NAFLD and the risk of ECC, pooled OR of ECC from four studies was analyzed [37, 40, 41, 43]. A meta-analysis was conducted with the random-effect model $(P=0.024, P=68.04 \%)$. The results showed that the risk of developing ECC was significantly higher in patients with NAFLD (OR $=2.24,95 \% \mathrm{Cl}: 1.58-3.17$ ) than in patients without NAFLD (Table 1, Figure 3B). These results suggest that NAFLD may increase the risk of developing ICC and ECC.

\section{Association between NAFLD and breast cancer}

In this systematic review and meta-analysis, four studies were included to evaluate the relationship between NAFLD and the risk of developing breast cancer $[21,24,44,45]$. Among these studies, 2 were conducted in the United States, 1 was conducted in Korea, and 1 was conducted in Israel. Three of the studies were cohort studies, while the remaining study was a case-control study. NOS scores indicated that all four studies were high quality (Table 3 ). Based on the data in Table 1 and in Supplementary Figure 1, the pooled OR of breast cancer in patients with NAFLD was 1.68 (95\% Cl: 1.44-1.97), which suggests that patients with NAFLD are more susceptible to breast cancer.

\section{Associations between NAFLD and other cancers}

Three of the included studies evaluated the association between NAFLD and the risk of developing gastric cancer [21, 24, 27] (Supplementary Table 1). According to NOS scores, all three of these cohort studies were of high quality. The pooled OR of gastric cancer was 1.89 (95\% Cl: 1.31-2.71) (Table 1), which suggests that patients with NAFLD have a high risk of developing gastric cancer. Similarly, to investigate a possible association between NAFLD and the risk of developing pancreatic cancer, three studies were included $[21,24,46]$ (Supplementary Table 1). All three cohort studies were of high quality according to their NOS scores. The pooled OR of pancreatic cancer was 2.12 (95\% Cl: 1.58-2.83) (Table 1), which suggests that patients with NAFLD have a high risk of developing pancreatic cancer. In addition, it was observed that patients with NAFLD have a high risk of developing prostate cancer (OR $=1.36$, 95\% Cl: $1.03-$ 1.79) (Tables 1 and Supplementary Table 1). Furthermore, two of the studies reported an association between NAFLD and a risk of developing esophageal cancer [21, 24], with the OR value of esophageal cancer being 1.77 (95\% Cl: 1.19-2.62) (Tables 1 and Supplementary Table 1).

\section{Discussion}

NAFLD is an epidemic of chronic liver disease worldwide, and it is the manifestation of metabolic syndrome in the liver [3]. Accumulating evidences suggest that NAFLD is tightly associated with various diseases, including diabetes, cardiovascular disease, kidney disease, and cancer [11-13, 49]. In recent years, more attentions have been paid to the possible association between NAFLD and the risk of certain cancers. For example, clinical observational studies have been conducted which investigate the relationship between NAFLD and the risks of developing cancer, especially extrahepatic cancers such as colon, stomach, and pancreas. Both Kim et al. and Allen et al. have conducted reviews regarding this issue [21, 24]. However, the results could not reflect the newest conclusion of the association between NAFLD and extrahepatic cancers absolutely. With the publication of new studies, a lastest summary is needed to expound the new research progresses in ths issue. Therefore, the newest systematic reviews and meta-analysis were conducted to investigate the association of NAFLD with the risk of various extrahepatic cancers comprehensively in this study.

In this study, the relationship of NAFLD with gastrointestinal cancers (colorectal cancer and colorectal adenoma), cholangiocarcinomas (ICC and ECC), and other cancers (including breast, gastric, pancreatic, prostate, and esophageal) were investigated. The results obtained suggest that NAFLD is tightly associated with all of these extrahepatic cancers. However, detailed mechanism(s) to explain how NAFLD promotes tumorigenesis remain unclear. NAFLD is caused by excessive accumulation of triglycerides, which could be regarded as a type of visceral adiposity [50]. Previous reports have suggested that visceral adipose tissue may affect the function of other organs by releasing cytokines such as adipocytokines, growth factors, and some pro-inflammatory factors [51]. This hypothesis, if confirmed, could provide valuable insight into the mechanism of NAFLD in tumorigenesis.

In a previous meta-analysis which investigated the association of incident and recurrent colorectal cancer and adenoma with NAFLD, it was observed that the presence and severity of NAFLD were associated with an increased risk of incident colorectal cancer or adenomas [52]. When Mantovani et al. examined the association between NAFLD and colorectal tumors in asymptomatic adults who underwent a screening colonoscopy, they found that NAFLD was associated with a moderate increase in the risk of colorectal cancer and adenoma [53]. In the present study, both inclusion and exclusion criteria were strictly adhered to, and all suitable studies were included to investigate the association of NAFLD with the risk of developing colorectal cancer and colorectal adenoma. Our results show that NAFLD significantly increases the risk of colorectal cancer $(\mathrm{OR}=1.72,95 \% \mathrm{Cl}$ : $1.40-2.11)$ and the risk of colorectal adenoma $(\mathrm{OR}=1.38$, $95 \% \mathrm{Cl}: 1.22-1.56)$ compared to healthy controls. These results are consistent with those of previous studies, and they support further investigations of the mechanism(s) by which NAFLD promotes the development of colorectal cancer and colorectal adenoma.

The associations between NAFLD and other extrahepatic cancers is less proven [54]. When Wongjarupong et al. conducted a meta-analysis to investigate a possible relationship between NAFLD and cholangiocarcinoma, they found that NAFLD was associated with both ICC (OR $=2.22,95 \%$ Cl: $1.52-3.24)$ and ECC $(\mathrm{OR}=1.55,95 \% \mathrm{Cl}: 1.03-2.33)$ [19]. In this study, the most recent publications available were added to conduct our meta-analysis. The results obtained show that NAFLD significantly increases the risk of developing both ICC $(\mathrm{OR}=2.40,95 \% \mathrm{Cl}: 1.75-3.31)$ and ECC $(\mathrm{OR}=2.24,95 \% \mathrm{Cl}$ : $1.58-3.17)$. These results are consistent with those of previous studies $[19,54]$. Furthermore, links between NAFLD and breast, gastric, pancreatic, prostate, and esophageal cancers were also reviewed. Sorensen et al. have reported that patients with NAFLD in the Danish population exhibit an increased risk of lung cancer and renal cell 
carcinoma [55]. Similarly, Watanabe et al. have verified that NAFLD may be associated with more severe renal cell carcinoma and shorter overall survival in Japanese populations $[55,56]$. However, relationships between NAFLD and lung cancer and renal cell carcinoma remain to be further studied as available data are currently insufficient. In addition, clinical studies are needed to further investigate the association between NAFLD and extrahepatic cancers. A recent study demonstrated that patients with NAFLD are more likely to exhibit chronic inflammation with insulin resistance, which may generate a microenvironment conducive for cancer development $[57,58]$. Emerging translational and epidemiologic data support that local ectopic fat may also affect functional factors, and in turn the paracrine pathway, to induce cancer development in the liver, pancreas, and breast $[59,60]$. Therefore, the results of the present study are consistent with those of previous studies and they indicate that NAFLD is a risk factor for various cancers, including cancer in the liver and extrahepatic cancers.

There were several limitations in this study. First, the tight association between NAFLD and extrahepatic cancers was investigated, but the degrees of NAFLD did not be classified. Consequently, the association of NAFLD severity with the extrahepatic cancers examined was not demonstrated. Second, a small number of studies were available to analyze the association between NAFLD and the risks of gastric, pancreatic, prostate, and esophageal cancers. Therefore, further studies are needed to focus on the risk of these extrahepatic cancers in patients with NAFLD. Third, many of the studies examined were conducted in East Asia. However, the ethnicity of the subjects in each study were not defined. Given that the risks of developing NAFLD and various cancers differ according to ethnicity, the influence of ethnicity on the relationship between NAFLD and extrahepatic cancers should be investigated in future studies.

\section{Conclusion}

In summary, the systematic review and meta-analysis was conducted to comprehensively investigate associations between NAFLD and the risk of developing extrahepatic cancers. The results indicate that NAFLD can significantly increase the risk of developing colorectal cancer and colorectal adenoma, ICC and ECC, and breast, gastric, pancreatic, prostate, and esophageal cancers. However, the evidence for an association of NAFLD with various extrahepatic cancers remains insufficient. In addition, mechanistic details regarding the capacity for NAFLD to promote tumorigenesis remains unclear. Both of these aspects are important to consider in future studies.

\section{Abbreviations}

$\mathrm{Cl}$, confidence interval; ECC, extrahepatic cholangiocarcinoma; HR, hazard ratio; ICC, intrahepatic cholangiocarcinoma; ICD-9, International Classification of Diseases, Ninth Revision; IRR, incidence rate ratio; NAFLD, nonalcoholic fatty liver disease; NASH, nonalcoholic steatohepatitis; NOS, Newcastle-Ottawa Scale; OR, odds ratio; PRISMA, Preferred Reporting Items for Systematic Reviews and Meta-Analyses.

\section{Declarations}

\section{Ethics approval and consent to participate}

Not applicable.

\section{Consent for publication}

Not applicable.

\section{Availability of data and materials}

The datasets used and/or analyzed during the current study are available from the corresponding author upon reasonable request.

\section{Competing interests}

The authors declare that they have no competing interests.

\section{Funding}

This study was supported by Grants of National Natural Science Foundation of China (31770837).

\section{Authors' Contributions}

Study concept and design: LSS and XYN. Acquisition and analysis of data: LSS, MXF, ZJ, DSX, ZJ, and DMZ. Drafts and writing of the manuscript: LSS and MXF. Revision of the manuscript: XYN. All authors approved the final manuscript.

\section{Acknowledgements}

We thank Bao-Kai Sun for the assistance and support he provided for this study.

\section{References}

1. European Association for the Study of the L, European Association for the Study of D, European Association for the Study of O: EASL-EASD-EASO Clinical Practice Guidelines for the management of non-alcoholic fatty liver disease. J Hepatol 2016, 64:1388-1402. 
2. Lonardo A, Nascimbeni F, Maurantonio M, Marrazzo A, Rinaldi L, Adinolfi LE: Nonalcoholic fatty liver disease: Evolving paradigms. World J Gastroenterol 2017, 23:6571-6592.

3. Younossi ZM, Koenig AB, Abdelatif D, Fazel Y, Henry L, Wymer M: Global epidemiology of nonalcoholic fatty liver disease-Meta-analytic assessment of prevalence, incidence, and outcomes. Hepatology 2016, 64:73-84.

4. Li J, Zou B, Yeo YH, Feng Y, Xie X, Lee DH, Fujii H, Wu Y, Kam LY, Ji F, et al: Prevalence, incidence, and outcome of non-alcoholic fatty liver disease in Asia, 1999-2019: a systematic review and meta-analysis. Lancet Gastroenterol Hepatol 2019, 4:389-398.

5. Diehl AM, Day C: Cause, Pathogenesis, and Treatment of Nonalcoholic Steatohepatitis. N Engl J Med 2017, 377:2063-2072.

6. Fan JG, Kim SU, Wong VW: New trends on obesity and NAFLD in Asia. J Hepatol 2017, 67:862-873.

7. Chang Y, Jung HS, Cho J, Zhang Y, Yun KE, Lazo M, Pastor-Barriuso R, Ahn J, Kim CW, Rampal S, et al: Metabolically Healthy Obesity and the Development of Nonalcoholic Fatty Liver Disease. Am J Gastroentero/ 2016, 111:1133-1140.

8. Koo BK, Kim D, Joo SK, Kim JH, Chang MS, Kim BG, Lee KL, Kim W: Sarcopenia is an independent risk factor for non-alcoholic steatohepatitis and significant fibrosis. J Hepatol 2017, 66:123-131.

9. Wong VW, Wong GL, Tse CH, Chan HL: Prevalence of the TM6SF2 variant and non-alcoholic fatty liver disease in Chinese. J Hepatol 2014, 61:708-709.

10. Li Y, Xu C, Yu C, Xu L, Miao M: Association of serum uric acid level with non-alcoholic fatty liver disease: a cross-sectional study. $J$ Hepato/ 2009, 50:10291034.

11. Cusi K, Sanyal AJ, Zhang S, Hartman ML, Bue-Valleskey JM, Hoogwerf BJ, Haupt A: Non-alcoholic fatty liver disease (NAFLD) prevalence and its metabolic associations in patients with type 1 diabetes and type 2 diabetes. Diabetes Obes Metab 2017, 19:1630-1634.

12. Targher G, Byrne CD, Lonardo A, Zoppini G, Barbui C: Non-alcoholic fatty liver disease and risk of incident cardiovascular disease: A meta-analysis. J Hepatol 2016, 65:589-600.

13. Armstrong MJ, Adams LA, Canbay A, Syn WK: Extrahepatic complications of nonalcoholic fatty liver disease. Hepatology 2014, 59:1174-1197.

14. Byrne CD, Targher G: NAFLD: a multisystem disease. J Hepatol 2015, 62:S47-64.

15. Chacko KR, Reinus J: Extrahepatic Complications of Nonalcoholic Fatty Liver Disease. Clin Liver Dis 2016, 20:387-401.

16. Younossi ZM, Golabi P, de Avila L, Paik JM, Srishord M, Fukui N, Qiu Y, Burns L, Afendy A, Nader F: The global epidemiology of NAFLD and NASH in patients with type 2 diabetes: A systematic review and meta-analysis. $J$ Hepatol 2019, 71:793-801.

17. Angulo P: Long-term mortality in nonalcoholic fatty liver disease: is liver histology of any prognostic significance? Hepatology 2010, 51:373-375.

18. Tilg H, Moschen AR: Mechanisms behind the link between obesity and gastrointestinal cancers. Best Pract Res Clin Gastroenterol 2014, 28:599-610.

19. Wongjarupong N, Assavapongpaiboon B, Susantitaphong P, Cheungpasitporn W, Treeprasertsuk S, Rerknimitr R, Chaiteerakij R: Non-alcoholic fatty liver disease as a risk factor for cholangiocarcinoma: a systematic review and meta-analysis. BMC Gastroenterol 2017, 17:149.

20. Lee JM, Park YM, Yun JS, Ahn YB, Lee KM, Kim DB, Lee JM, Han K, Ko SH: The association between nonalcoholic fatty liver disease and esophageal, stomach, or colorectal cancer: National population-based cohort study. PLoS One 2020, 15:e0226351.

21. Allen AM, Hicks SB, Mara KC, Larson JJ, Therneau TM: The risk of incident extrahepatic cancers is higher in non-alcoholic fatty liver disease than obesity A longitudinal cohort study. J Hepatol 2019, 71:1229-1236.

22. Shamseer L MD, Clarke M, et al. BMJ. 2015;349(1):g7647.: Preferred reporting items for systematic review and meta-analysis protocols (PRISMA-P) 2015: elaboration and explanation. BMJ 2015;349(1):g7647.

23. G . A . W e I I s BShea DOConnelletal: The Newcastle-Ottawa Scale (NOS) for Assessing the Quality of Nonrandomised Studies in Meta-analyses. . 2012.

24. Kim GA, Lee HC, Choe J, Kim MJ, Lee MJ, Chang HS, Bae IY, Kim HK, An J, Shim JH, et al: Association between non-alcoholic fatty liver disease and cancer incidence rate. $J$ Hepatol 2017.

25. Ahn JS, Sinn DH, Min YW, Hong SN, Kim HS, Jung SH, Gu S, Rhee PL, Paik SW, Son HJ, Gwak GY: Non-alcoholic fatty liver diseases and risk of colorectal neoplasia. Aliment Pharmacol Ther 2017, 45:345-353.

26. Chen ZF, Dong XL, Huang QK, Hong WD, Wu WZ, Wu JS, Pan S: The combined effect of non-alcoholic fatty liver disease and metabolic syndrome on colorectal carcinoma mortality: a retrospective in Chinese females. World J Surg Oncol 2018, 16:163.

27. Hamaguchi M, Hashimoto Y, Obora A, Kojima T, Fukui M: Non-alcoholic fatty liver disease with obesity as an independent predictor for incident gastric and colorectal cancer: a population-based longitudinal study. BMJ Open Gastroenterol 2019, 6:e000295.

28. Lee T, Yun KE, Chang Y, Ryu S, Park DI, Choi K, Jung YS: Risk of Colorectal Neoplasia According to Fatty Liver Severity and Presence of Gall Bladder Polyps. Dig Dis Sci 2016, 61:317-324.

29. Lee YI, Lim YS, Park HS: Colorectal neoplasms in relation to non-alcoholic fatty liver disease in Korean women: a retrospective cohort study. $J$ Gastroenterol Hepatol 2012, 27:91-95.

30. Lin XF, Shi KQ, You J, Liu WY, Luo YW, Wu FL, Chen YP, Wong DK, Yuen MF, Zheng MH: Increased risk of colorectal malignant neoplasm in patients with nonalcoholic fatty liver disease: a large study. Mol Biol Rep 2014, 41:2989-2997.

31. Pan S, Hong W, Wu W, Chen Q, Zhao Q, Wu J, Jin Y: The relationship of nonalcoholic fatty liver disease and metabolic syndrome for colonoscopy colorectal neoplasm. Medicine (Baltimore) 2017, 96:e5809.

32. Yang YJ, Bang CS, Shin SP, Baik GH: Clinical impact of non-alcoholic fatty liver disease on the occurrence of colorectal neoplasm: Propensity score matching analysis. PLoS One 2017, 12:e0182014.

33. Huang KW, Leu HB, Wang YJ, Luo JC, Lin HC, Lee FY, Chan WL, Lin JK, Chang FY: Patients with nonalcoholic fatty liver disease have higher risk of colorectal adenoma after negative baseline colonoscopy. Colorectal Dis 2013, 15:830-835.

Page $6 / 13$ 
34. Hwang ST, Cho YK, Park JH, Kim HJ, Park DI, Sohn Cl, Jeon WK, Kim BI, Won KH, Jin W: Relationship of non-alcoholic fatty liver disease to colorectal adenomatous polyps. J Gastroenterol Hepatol 2010, 25:562-567.

35. Stadlmayr A, Aigner E, Steger B, Scharinger L, Lederer D, Mayr A, Strasser M, Brunner E, Heuberger A, Hohla F, et al: Nonalcoholic fatty liver disease: an independent risk factor for colorectal neoplasia. J Intern Med 2011, 270:41-49.

36. Wong VW, Wong GL, Tsang SW, Fan T, Chu WC, Woo J, Chan AW, Choi PC, Chim AM, Lau JY, et al: High prevalence of colorectal neoplasm in patients with non-alcoholic steatohepatitis. Gut 2011, 60:829-836.

37. Chang JS, Tsai CR, Chen LT: Medical risk factors associated with cholangiocarcinoma in Taiwan: a population-based case-control study. PLoS One 2013, 8:e69981.

38. Choi J, Ghoz HM, Peeraphatdit T, Baichoo E, Addissie BD, Harmsen WS, Therneau TM, Olson JE, Chaiteerakij R, Roberts LR: Aspirin use and the risk of cholangiocarcinoma. Hepatology 2016, 64:785-796.

39. Kinoshita M, Kubo S, Tanaka S, Takemura S, Nishioka T, Hamano G, Ito T, Tanaka S, Ohsawa M, Shibata T: The association between non-alcoholic steatohepatitis and intrahepatic cholangiocarcinoma: A hospital based case-control study. J Surg Oncol 2016, 113:779-783.

40. Lee BS, Cha BH, Park EC, Roh J: Risk factors for perihilar cholangiocarcinoma: a hospital-based case-control study. Liver Int 2015, 35:1048-1053.

41. Petrick JL, Yang B, Altekruse SF, Van Dyke AL, Koshiol J, Graubard BI, McGlynn KA: Risk factors for intrahepatic and extrahepatic cholangiocarcinoma in the United States: A population-based study in SEER-Medicare. PLoS One 2017, 12:e0186643.

42. Stepien M, Fedirko V, Duarte-Salles T, Ferrari P, Freisling H, Trepo E, Trichopoulou A, Bamia C, Weiderpass E, Olsen A, et al: Prospective association of liver function biomarkers with development of hepatobiliary cancers. Cancer Epidemio/ 2016, 40:179-187.

43. Welzel TM, Graubard BI, El-Serag HB, Shaib YH, Hsing AW, Davila JA, McGlynn KA: Risk factors for intrahepatic and extrahepatic cholangiocarcinoma in the United States: a population-based case-control study. Clin Gastroenterol Hepatol 2007, 5:1221-1228.

44. Kwak MS, Yim JY, Yi A, Chung GE, Yang JI, Kim D, Kim JS, Noh DY: Nonalcoholic fatty liver disease is associated with breast cancer in nonobese women. Dig Liver Dis 2019, 51:1030-1035.

45. Nseir W, Abu-Rahmeh Z, Tsipis A, Mograbi J, Mahamid M: Relationship between Non-Alcoholic Fatty Liver Disease and Breast Cancer. Isr Med Assoc J 2017, 19:242-245.

46. Chang CF, Tseng YC, Huang HH, Shih YL, Hsieh TY, Lin HH: Exploring the relationship between nonalcoholic fatty liver disease and pancreatic cancer by computed tomographic survey. Intern Emerg Med 2018, 13:191-197.

47. Chen QF, Zhou XD, Sun YJ, Fang DH, Zhao Q, Huang JH, Jin Y, Wu JS: Sex-influenced association of non-alcoholic fatty liver disease with colorectal adenomatous and hyperplastic polyps. World J Gastroenterol 2017, 23:5206-5215.

48. Cho Y, Lim SK, Joo SK, Jeong DH, Kim JH, Bae JM, Park JH, Chang MS, Lee DH, Jung YJ, et al: Nonalcoholic steatohepatitis is associated with a higher risk of advanced colorectal neoplasm. Liver Int 2019, 39:1722-1731.

49. Vongsuvanh R, George J, Qiao L, van der Poorten D: Visceral adiposity in gastrointestinal and hepatic carcinogenesis. Cancer Lett 2013, $330: 1-10$.

50. van der Poorten D, Milner KL, Hui J, Hodge A, Trenell MI, Kench JG, London R, Peduto T, Chisholm DJ, George J: Visceral fat: a key mediator of steatohepatitis in metabolic liver disease. Hepatology 2008, 48:449-457.

51. Despres JP, Lemieux I: Abdominal obesity and metabolic syndrome. Nature 2006, 444:881-887.

52. Chen J, Bian D, Zang S, Yang Z, Tian G, Luo Y, Yang J, Xu B, Shi J: The association between nonalcoholic fatty liver disease and risk of colorectal adenoma and cancer incident and recurrence: a meta-analysis of observational studies. Expert Rev Gastroenterol Hepatol 2019, 13:385-395.

53. Mantovani A, Dauriz M, Byrne CD, Lonardo A, Zoppini G, Bonora E, Targher G: Association between nonalcoholic fatty liver disease and colorectal tumours in asymptomatic adults undergoing screening colonoscopy: a systematic review and meta-analysis. Metabolism 2018, 87:1-12.

54. Sanna C, Rosso C, Marietti M, Bugianesi E: Non-Alcoholic Fatty Liver Disease and Extra-Hepatic Cancers. Int J Mol Sci $2016,17$.

55. Sorensen HT, Mellemkjaer L, Jepsen P, Thulstrup AM, Baron J, Olsen JH, Vilstrup H: Risk of cancer in patients hospitalized with fatty liver: a Danish cohort study. J Clin Gastroentero/ 2003, 36:356-359.

56. Watanabe D, Horiguchi A, Tasaki S, Kuroda K, Sato A, Asakuma J, Ito K, Asano T, Shinmoto H: Clinical implication of ectopic liver lipid accumulation in renal cell carcinoma patients without visceral obesity. Sci Rep 2017, 7:12795.

57. Gilbert CA, Slingerland JM: Cytokines, obesity, and cancer: new insights on mechanisms linking obesity to cancer risk and progression. Annu Rev Med 2013, 64:45-57.

58. Hui JM, Hodge A, Farrell GC, Kench JG, Kriketos A, George J: Beyond insulin resistance in NASH: TNF-alpha or adiponectin? Hepatology 2004, 40:46-54.

59. Hori M, Takahashi M, Hiraoka N, Yamaji T, Mutoh M, Ishigamori R, Furuta K, Okusaka T, Shimada K, Kosuge T, et al: Association of pancreatic Fatty infiltration with pancreatic ductal adenocarcinoma. Clin Trans/ Gastroenterol 2014, 5:e53.

60. Lashinger LM, Malone LM, McArthur MJ, Goldberg JA, Daniels EA, Pavone A, Colby JK, Smith NC, Perkins SN, Fischer SM, Hursting SD: Genetic reduction of insulin-like growth factor-1 mimics the anticancer effects of calorie restriction on cyclooxygenase-2-driven pancreatic neoplasia. Cancer Prev Res (Phila) 2011, 4:1030-1040.

\section{Tables}

Table 1. Summarization of the relationship between NAFLD and all kinds of extrahepatic cancers. 


\begin{tabular}{lccccc}
\hline Types of Cancer & Number of studies & OR/HR/IRR & $\mathbf{( 9 5 \% C I )}$ & $\boldsymbol{I}^{2}$ & $\boldsymbol{P}$ value \\
\hline Gastrointestinal cancers & & & & & \\
$\quad$ Colorectal cancer & 10 & 1.72 & $1.40-2.11$ & $83.50 \%$ & $<0.01$ \\
\hline$\quad$ Colorectal adenomas & 9 & 1.38 & $1.22-1.56$ & $49.40 \%$ & 0.045 \\
\hline Cholangiocarcinoma & & & & & \\
\hline$\quad$ Intrahepatic cholangiocarcinoma & 7 & 2.40 & $1.75-3.31$ & $68.40 \%$ & 0.004 \\
\hline$\quad$ Extrahepatic cholangiocarcinoma & 4 & 2.24 & $1.58-3.17$ & $68.04 \%$ & 0.023 \\
\hline Breast cancer & 4 & 1.68 & $1.44-1.97$ & $0.00 \%$ & 0.727 \\
\hline Gastric cancer & 3 & 1.89 & $1.31-2.71$ & $49.60 \%$ & 0.094 \\
\hline Pancreatic cancer & 3 & 2.12 & $1.58-2.83$ & $0.00 \%$ & 0.476 \\
\hline Prostate cancer & 3 & 1.36 & $1.03-1.79$ & $81.90 \%$ & 0.001 \\
\hline Esophagus cancer & 2 & 1.77 & $1.19-2.62$ & $0.00 \%$ & 0.983 \\
\hline
\end{tabular}

Abbreviation: OR, odds ratio; HR, hazard ratio; IRR, incidence rate ratio. CI: confidence interval.

Table 2. The association between NAFLD and colorectal adenomas or colorectal cancer. 


\begin{tabular}{lllllll}
\hline Study & Country & Sample & NAFLD diagnosis & Patients source & Date & Study Colorectal cancer Adjusted
\end{tabular}

\begin{tabular}{|c|c|c|c|c|c|c|c|}
\hline & & size & & & & design & diagnosis \\
\hline $\begin{array}{l}\text { Chen et al. } \\
2018 \text { [26] }\end{array}$ & China & 764 & Ultrasonography & Community & $\begin{array}{l}2014- \\
2016\end{array}$ & $\begin{array}{c}\text { Cross- } \\
\text { sectional }\end{array}$ & Colonoscop \\
\hline $\begin{array}{l}\text { Ahn et al. } \\
2017 \text { [25] }\end{array}$ & $\begin{array}{l}\text { South } \\
\text { Korea }\end{array}$ & 26540 & Ultrasonography & Community & $\begin{array}{l}2003- \\
2012\end{array}$ & $\begin{array}{l}\text { Cross- } \\
\text { sectional }\end{array}$ & Histology \\
\hline
\end{tabular}

confoundin

quality factors

Good

smoking,

alcohol

metabolic

syndrome

Age, sex, BMI, Good smoking, alcohol

intake, first

degree family

history of

colorectal

cancer,

aspirin use,

fasting plasma

glucose, total

cholesterol,

triglycerides,

systolic blood

pressure, use of any

hypoglycemic anti-

hypertensive

drugs or use of statin

\begin{tabular}{|c|c|c|c|c|c|c|c|c|c|}
\hline $\begin{array}{l}\text { Chen et al. } \\
2017 \text { [47] }\end{array}$ & China & 3686 & Ultrasonography & Hospital & $\begin{array}{l}2007- \\
2014\end{array}$ & $\begin{array}{l}\text { Cross- } \\
\text { sectional }\end{array}$ & Endoscopy & $\begin{array}{c}\text { Age, CEA, } \\
\text { stage, tumor } \\
\text { location, and } \\
\text { tumor } \\
\text { differentiation }\end{array}$ & Good \\
\hline $\begin{array}{l}\text { Pan et al. } \\
2017 \text { [31] }\end{array}$ & China & 1793 & Ultrasonography & Community & $\begin{array}{l}2011- \\
2015\end{array}$ & $\begin{array}{l}\text { Cross- } \\
\text { sectional }\end{array}$ & Colonoscopy & $\begin{array}{l}\text { Age, sex, ALT, } \\
\text { uric acid, } \\
\text { metabolic } \\
\text { syndrome }\end{array}$ & Good \\
\hline $\begin{array}{l}\text { Lee et al. } \\
2016[28]\end{array}$ & $\begin{array}{l}\text { South } \\
\text { Korea }\end{array}$ & 44221 & Ultrasonography & Community & $\begin{array}{l}2010- \\
2011\end{array}$ & $\begin{array}{l}\text { Cross- } \\
\text { sectional }\end{array}$ & Colonoscopy & $\begin{array}{c}\text { Age, sex, BMI, } \\
\text { smoking, } \\
\text { family history } \\
\text { of colorectal } \\
\text { cancer, } \\
\text { aspirin use, } \\
\text { hypertension, } \\
\text { diabetes } \\
\text { mellitus }\end{array}$ & Good \\
\hline
\end{tabular}

\begin{tabular}{|c|c|c|c|c|c|c|c|c|c|}
\hline $\begin{array}{l}\text { Lin et al. } \\
2014^{[30]}\end{array}$ & China & 2314 & Ultrasonography & Hospital & $\begin{array}{l}2007- \\
2011\end{array}$ & $\begin{array}{l}\text { Cross- } \\
\text { sectional }\end{array}$ & Colonoscopy & $\begin{array}{c}\text { Age, sex, BMI, } \\
\text { hypertension, } \\
\text { plasma } \\
\text { triglycerides, } \\
\text { uric acid, } \\
\text { ALT, albumin, } \\
\text { hemoglobin, } \\
\text { platelet count }\end{array}$ & Fair \\
\hline $\begin{array}{l}\text { Wong et al. } \\
2011 \text { [36] }\end{array}$ & China & 380 & $\begin{array}{c}{ }^{1} \mathrm{H}-\mathrm{MRS} / \text { Liver } \\
\text { biopsy }\end{array}$ & Community/Hospital & $\begin{array}{l}2008- \\
2010\end{array}$ & $\begin{array}{l}\text { Cross- } \\
\text { sectional }\end{array}$ & Colonoscopy & $\begin{array}{l}\text { Age, sex, BMI, } \\
\text { smoking, } \\
\text { family history } \\
\text { of colorectal } \\
\text { cancer, } \\
\text { hypertension, } \\
\text { diabetes } \\
\text { mellitus }\end{array}$ & Good \\
\hline
\end{tabular}

\begin{tabular}{|c|c|c|c|c|c|c|c|c|c|}
\hline $\begin{array}{l}\text { Stadlmayr } \\
\text { et al. } 2011 \\
\text { [35] }\end{array}$ & Austria & 1211 & Ultrasonography & Hospital & $\begin{array}{l}2007- \\
2009\end{array}$ & $\begin{array}{l}\text { Cross- } \\
\text { sectional }\end{array}$ & Colonoscopy & $\begin{array}{l}\text { Age, sex, BMI, } \\
\text { glucose } \\
\text { intolerance } \\
\text { status } \\
\text { (impaired } \\
\text { fasting } \\
\text { glycaemia or } \\
\text { diabetes } \\
\text { mellitus) }\end{array}$ & Good \\
\hline $\begin{array}{l}\text { Hwang et } \\
\text { al. } 2010 \\
\text { [34] }\end{array}$ & $\begin{array}{l}\text { South } \\
\text { Korea }\end{array}$ & 2917 & Ultrasonography & Hospital & 2007 & $\begin{array}{l}\text { Cross- } \\
\text { sectional }\end{array}$ & Colonoscopy & $\begin{array}{c}\text { Age, sex, } \\
\text { smoking, } \\
\text { hypertension, } \\
\text { diabetes } \\
\text { mellitus, } \\
\text { metabolic } \\
\text { syndrome }\end{array}$ & Good \\
\hline $\begin{array}{l}\text { Allen et al. } \\
2019 \text { [21] }\end{array}$ & USA & 276 & HCIDA/ICD-9 & Community & $\begin{array}{l}1997- \\
2016\end{array}$ & Cohort & ICD-9 & NA & Good \\
\hline
\end{tabular}




\begin{tabular}{|c|c|c|c|c|c|c|c|c|c|}
\hline $\begin{array}{l}\text { Hamaguchi } \\
\text { et al. } 2019 \\
\text { [27] }\end{array}$ & Japan & 15926 & Ultrasonography & Community & $\begin{array}{l}2004- \\
2016\end{array}$ & Cohort & Endoscopy & $\begin{array}{l}\text { Sex, age and } \\
\text { lifestyle } \\
\text { factors } \\
\text { including } \\
\text { smoking } \\
\text { habits, } \\
\text { alcoholic } \\
\text { consumption } \\
\text { and physical } \\
\text { activities and } \\
\text { diabetes }\end{array}$ & Good \\
\hline $\begin{array}{l}\text { Kim et al. } \\
2018[24]\end{array}$ & $\begin{array}{l}\text { South } \\
\text { Korea }\end{array}$ & NA & Ultrasonography & Community & $\begin{array}{l}2004- \\
2005\end{array}$ & Cohort & Pathology & $\begin{array}{l}\text { Demographic } \\
\text { and metabolic } \\
\text { factors }\end{array}$ & Good \\
\hline $\begin{array}{l}\text { Yang et al. } \\
2017 \text { [32] }\end{array}$ & $\begin{array}{l}\text { South } \\
\text { Korea }\end{array}$ & 882 & $\begin{array}{l}\text { Ultrasonography/ } \\
\text { computed } \\
\text { tomography }\end{array}$ & Hospital & $\begin{array}{l}2009- \\
2013\end{array}$ & Cohort & Colonoscopy & $\begin{array}{c}\text { Age, sex, } \\
\text { smoking, } \\
\text { hypertension, } \\
\text { diabetes } \\
\text { mellitus, use } \\
\text { of aspirin or } \\
\text { lipid-lowering } \\
\text { agents; } \\
\text { imaging for } \\
\text { diagnosis of } \\
\text { NAFLD }\end{array}$ & Fair \\
\hline $\begin{array}{l}\text { Huang et } \\
\text { al. } 2013 \\
\text { [33] }\end{array}$ & $\begin{array}{l}\text { South } \\
\text { Korea }\end{array}$ & 1522 & Ultrasonography & Hospital & $\begin{array}{l}2003- \\
2010\end{array}$ & Cohort & Colonoscopy & $\begin{array}{l}\text { Age, sex, BMI, } \\
\text { smoking, } \\
\text { hypertension, } \\
\text { diabetes } \\
\text { mellitus, } \\
\text { metabolic } \\
\text { syndrome }\end{array}$ & Fair \\
\hline $\begin{array}{l}\text { Lee et al. } \\
2012^{[29]}\end{array}$ & $\begin{array}{l}\text { South } \\
\text { Korea }\end{array}$ & 5517 & Ultrasonography & Hospital & $\begin{array}{l}2002- \\
2006\end{array}$ & Cohort & Colonoscopy & $\begin{array}{l}\text { Age, BMI, } \\
\text { smoking, } \\
\text { hypertension, } \\
\text { dyslipidemia, } \\
\text { fasting } \\
\text { glucose level }\end{array}$ & Fair \\
\hline
\end{tabular}

Abbreviation: HICDA, Hospital International Classification of Diseases Adapted; ICD, International Classification of Diseases.

Table 3. The association between NAFLD with cholangiocarcinoma and breast cancer. 


\begin{tabular}{|c|c|c|c|c|c|c|c|c|c|}
\hline & Study & Country & $\begin{array}{c}\text { Sample } \\
\text { size }\end{array}$ & NAFLD diagnosis & $\begin{array}{l}\text { Patients } \\
\text { source }\end{array}$ & Date & $\begin{array}{l}\text { Study } \\
\text { design }\end{array}$ & $\begin{array}{c}\text { Cancer } \\
\text { diagnosis }\end{array}$ & $\begin{array}{c}\text { Adjusted } \\
\text { confounding } \\
\text { factors }\end{array}$ \\
\hline \multirow[t]{8}{*}{ Cholangiocarcinoma } & $\begin{array}{l}\text { Petrick } \\
\text { et al. } \\
2017 \text { [41] }\end{array}$ & US & 328688 & ICD-9 & Community & $\begin{array}{c}2000 \\
- \\
2011\end{array}$ & $\begin{array}{c}\text { Case- } \\
\text { control }\end{array}$ & ICD-9 & $\begin{array}{c}\text { Age, } \\
\text { race/ethnicity, } \\
\text { geographic } \\
\text { region, and } \\
\text { state buy-in } \\
\text { status }\end{array}$ \\
\hline & $\begin{array}{l}\text { Choi et } \\
\text { al. } 2016 \\
{[38]}\end{array}$ & US & 7164 & Histology/Imaging & Hospital & $\begin{array}{c}2000 \\
- \\
2014\end{array}$ & $\begin{array}{l}\text { Case- } \\
\text { control }\end{array}$ & ICD-9 & $\begin{array}{c}\text { The } \\
\text { differences in }\end{array}$ \\
\hline & & & & & & & & & $\begin{array}{c}\text { frequencies of } \\
\text { aspirin } \\
\text { current users }\end{array}$ \\
\hline & $\begin{array}{l}\text { Kinoshita } \\
\text { et al. } \\
2016 \\
{[39]}\end{array}$ & Japan & 103 & Histology & Hospital & $\begin{array}{c}1995 \\
- \\
2014\end{array}$ & $\begin{array}{l}\text { Case- } \\
\text { control }\end{array}$ & Pathology & NA \\
\hline & $\begin{array}{l}\text { Stepien } \\
\text { et al. } \\
2016 \text { [42] }\end{array}$ & Europe & 495 & $\begin{array}{c}\text { Hepatic steatosis } \\
\text { index }\end{array}$ & Community & $\begin{array}{c}1992 \\
- \\
2000\end{array}$ & $\begin{array}{l}\text { Case- } \\
\text { control }\end{array}$ & ICD-9 & $\begin{array}{c}\text { Smoking } \\
\text { status, } \\
\text { baseline, } \\
\text { lifetime } \\
\text { alcohol intake } \\
\text { pattern, body } \\
\text { mass index, } \\
\text { physical } \\
\text { activity, } \\
\text { hepatitis B, C } \\
\text { infection, } \\
\text { diabetes } \\
\text { status, CRP }\end{array}$ \\
\hline & $\begin{array}{l}\text { Lee et al. } \\
2015 \\
{[40]}\end{array}$ & $\begin{array}{l}\text { South } \\
\text { Korea }\end{array}$ & 243 & Histology/Imaging & Hospital & $\begin{array}{c}2007 \\
- \\
2013\end{array}$ & $\begin{array}{c}\text { Case- } \\
\text { control }\end{array}$ & Pathology & NA \\
\hline & $\begin{array}{l}\text { Chang et } \\
\text { al. } 2013 \\
\text { [37] }\end{array}$ & China & 25785 & ICD-9 & Community & $\begin{array}{c}2004 \\
- \\
2008\end{array}$ & $\begin{array}{l}\text { Case- } \\
\text { control }\end{array}$ & ICD-9 & $\begin{array}{c}\text { Possible } \\
\text { intermediate } \\
\text { factors }\end{array}$ \\
\hline & $\begin{array}{l}\text { Welzel et } \\
\text { al. } 2007 \\
{[43]}\end{array}$ & US & 103866 & ICD-9 & Community & $\begin{array}{c}1999 \\
- \\
2009\end{array}$ & $\begin{array}{l}\text { Case- } \\
\text { control }\end{array}$ & ICD-9 & NA \\
\hline \multirow[t]{4}{*}{ Breast cancer } & $\begin{array}{l}\text { Allen et } \\
\text { al. } 2019 \\
{[21]}\end{array}$ & USA & 676 & ICD-9 & Community & $\begin{array}{c}1997 \\
- \\
2016\end{array}$ & Cohort & ICD-9 & NA \\
\hline & $\begin{array}{l}\text { Kim et } \\
\text { al. } 2018 \\
{[24]}\end{array}$ & Korea & NA & Ultrasonography & Community & $\begin{array}{c}2004 \\
- \\
2005\end{array}$ & Cohort & $\begin{array}{l}\text { Pathology } \\
\text { radiology }\end{array}$ & $\begin{array}{c}\text { Demographic } \\
\text { and metabolic } \\
\text { factors }\end{array}$ \\
\hline & $\begin{array}{l}\text { Nseir et } \\
\text { al. } 2017 \\
{[45]}\end{array}$ & Israel & 146 & Ultrasonography & Community & $\begin{array}{c}2008 \\
- \\
2011\end{array}$ & Cohort & Ultrasonography & NA \\
\hline & $\begin{array}{l}\text { Kwak et } \\
\text { al. } 2019 \\
{[44]}\end{array}$ & USA & 540 & Ultrasonography. & Community & $\begin{array}{c}2008 \\
- \\
2017\end{array}$ & $\begin{array}{l}\text { Case- } \\
\text { control }\end{array}$ & Ultrasonography & NA \\
\hline
\end{tabular}

Abbreviation: ICD, International Classification of Diseases.

\section{Figures}




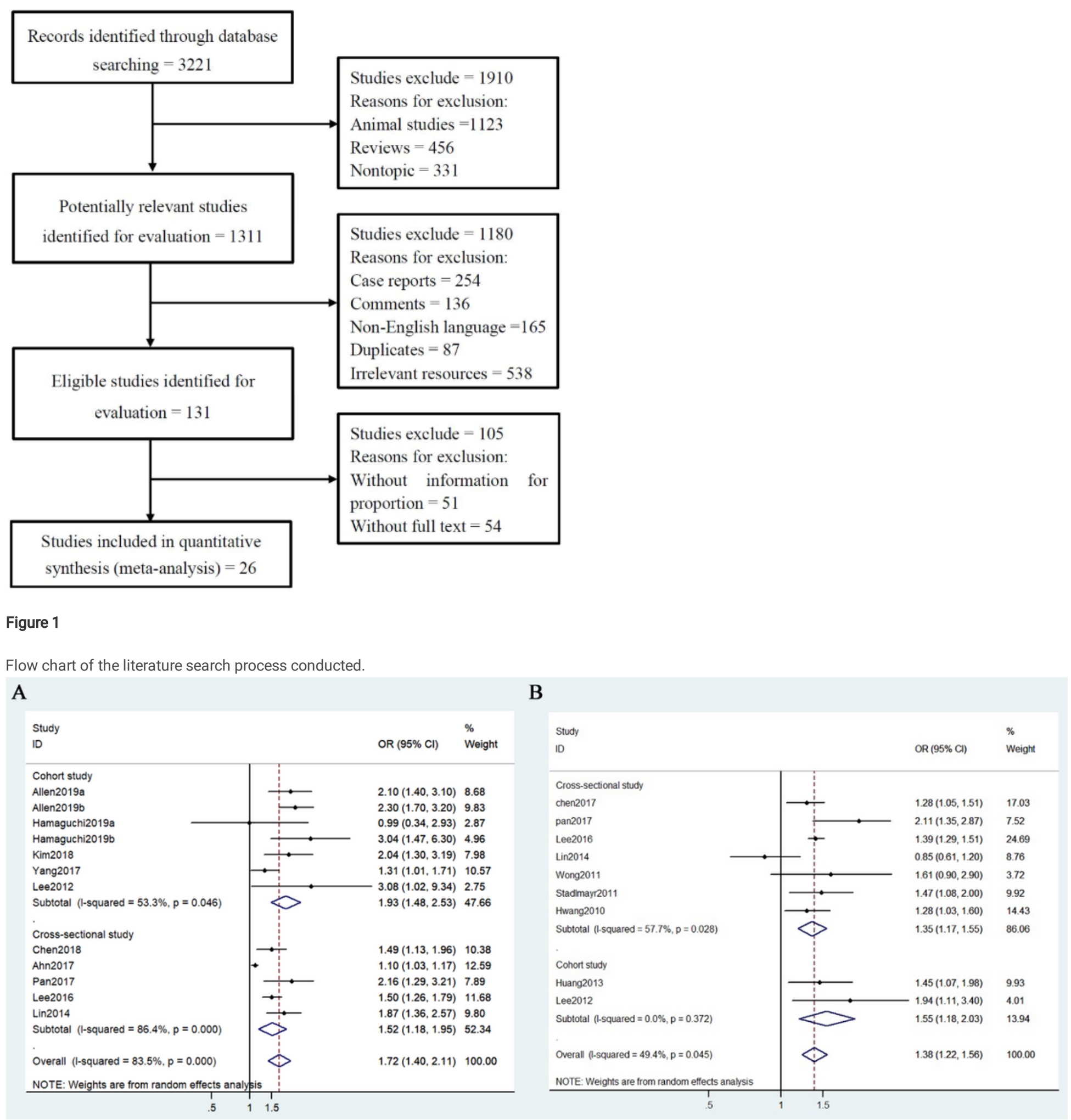

Figure 2

Meta-analysis of the association between NAFLD and colorectal cancer or colorectal adenomas. Forest plots are shown for colorectal cancer (A) and colorectal adenomas (B). 
A

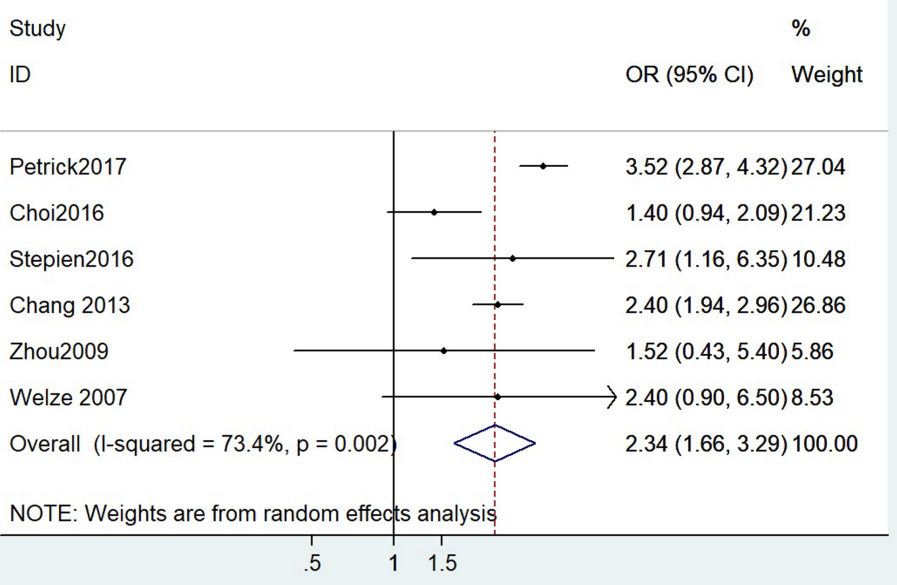

B

Study

ID

$\%$

OR $(95 \% \mathrm{Cl}) \quad$ Weight

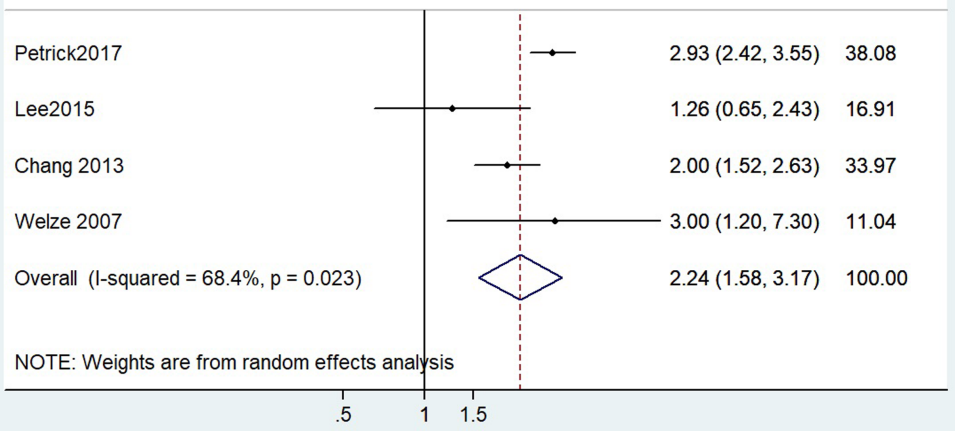

\section{Figure 3}

Meta-analysis of the association between NAFLD and cholangioarcinomas. Forest plots are shown for ICC (A) and ECC (B).

A

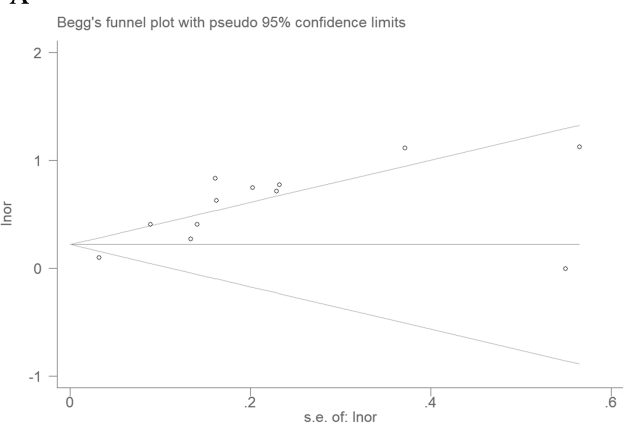

B

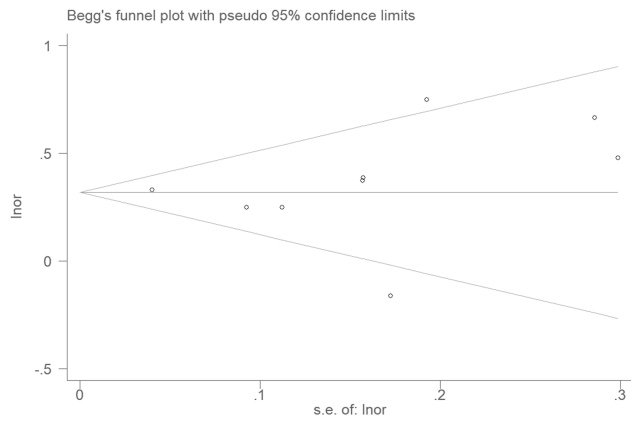

C

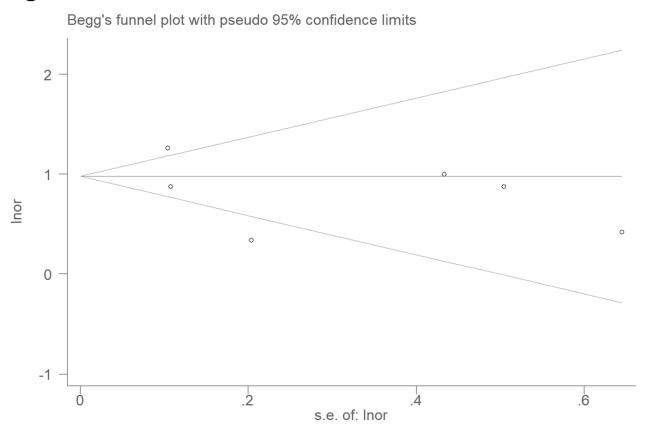

Figure 4

Begger's funnel plots for publication bias are shown for colorectal cancer (A), colorectal adenomas (B), and ICC (C).

\section{Supplementary Files}

This is a list of supplementary files associated with this preprint. Click to download.

- SupplementaryFigure.docx

- SupplementaryTables.docx 